\title{
Farming in Northern Ontario: Untapped Potential for the Future
}

\author{
Tejendra Chapagain
}

Department of Plant Agriculture, University of Guelph, Guelph, ON N1G 2W1, Canada; tejendra@uoguelph.ca; Tel.: +1-519-824-4120

Received: 15 July 2017; Accepted: 30 August 2017; Published: 6 September 2017

\begin{abstract}
Farming in Northern Ontario is limited to less than 1\% of the total land area available. With over 2000 farms, this is home to about $6 \%$ of the province's population, concentrated in the five major southern border cities of Thunder Bay, Sault Ste. Marie, Timmins, Sudbury and North Bay, with a significant presence of indigenous (i.e., First Nations) and disadvantaged peoples. This review highlights the challenges and opportunities of agriculture in Northern Ontario and offers a few strategies for establishing and sustaining agricultural operations locally. The challenges of farming in this region include the prevalence of adverse climatic conditions, lack of crop/economic diversification, insufficient infrastructure and support services, presence of small local markets, an aging population and youth out-migration, attitudes of dependency on government and limited investment potential. Nevertheless, this region offers much potential for farming as it contains significant amounts of fertile soils, good road networks and affordable land to start up farm businesses. Furthermore, the changing climate could be a boon to improve growing conditions, with expanded cropping options and increased yields in recent years. Production and consumption of local foods, conducting innovative on-farm research that addresses the needs of local producers including First Nations peoples, fostering regional research centres, building relationships through networking, exchange of ideas through effective use of different extension avenues, and collaboration and assisting local producers with market development may help establish a more competitive and sustainable agrifood sector in Northern Ontario. Favourable government policies to support growers who have experienced damage to their crops, forages and livestock due to adverse climatic conditions will further help sustain and expand their agricultural operations.
\end{abstract}

Keywords: northern Ontario agriculture; climate change; ecozone; drought; diversification

\section{Introduction}

Ontario, with more than half of the highest quality (Class 1) agricultural land in Canada, is home to 49,600 farms [1,2]. With over 200 different agricultural commodities, including fruit (e.g., apple, berries, grape and other tender fruits), vegetables (e.g., beans, beets, brassicas, onions, potatoes, spinach, kale, lettuce, peas, radishes, etc.), cash crops (e.g., corn, soybeans, oats, barley, winter wheat, mixed grains, etc.), livestock (e.g., commercial poultry, hog, dairy and beef cattle), forage crops, maple syrup, flowers and ornamental plants, on approximately 5.2 million hectares of farm and rangeland, its agricultural domain has been one of the most diversified and productive in Canada, producing almost one-quarter of all farm revenue in the country [1,2].

The Province consists of two primary regions: Northern Ontario and Southern Ontario (Figure 1). Northern Ontario occupies over $80 \%$ of the land area of the province, i.e., $802,000 \mathrm{~km}^{2}$; however, with just 732,900 people, it contains only about $6 \%$ of the province's population, with a significant presence of indigenous (i.e., First Nations) and disadvantaged peoples [1]. Despite the greater land extent, Northern Ontario only has 2391 farms (i.e., $5 \%$ of the farms in the province) encompassing 
362,000 hectares of farmland (i.e., $7 \%$ of the provincial area) and generating $\$ 199$ million in revenue (Table 1). Northern Ontario is further divided into two secondary regions: The three western-most districts (i.e., Kenora, Rainy River and Thunder Bay) constitute Northwestern Ontario $\left(526,373 \mathrm{~km}^{2}\right.$ area) while the other districts, which constitute Northeastern Ontario $\left(266,802 \mathrm{~km}^{2}\right.$ area), contain two-thirds of the population in Northern Ontario. Muskoka and Parry Sound districts are treated as part of Northern Ontario even though they are geographically in Southern Ontario. This is also because these are the service area of the Federal Economic Development Initiative for Northern Ontario (Fed-Nor), which is a program of Innovation, Science and Economic Development Canada with a mission of addressing economic development, diversification and job creation in Northern Ontario (Figure 1).

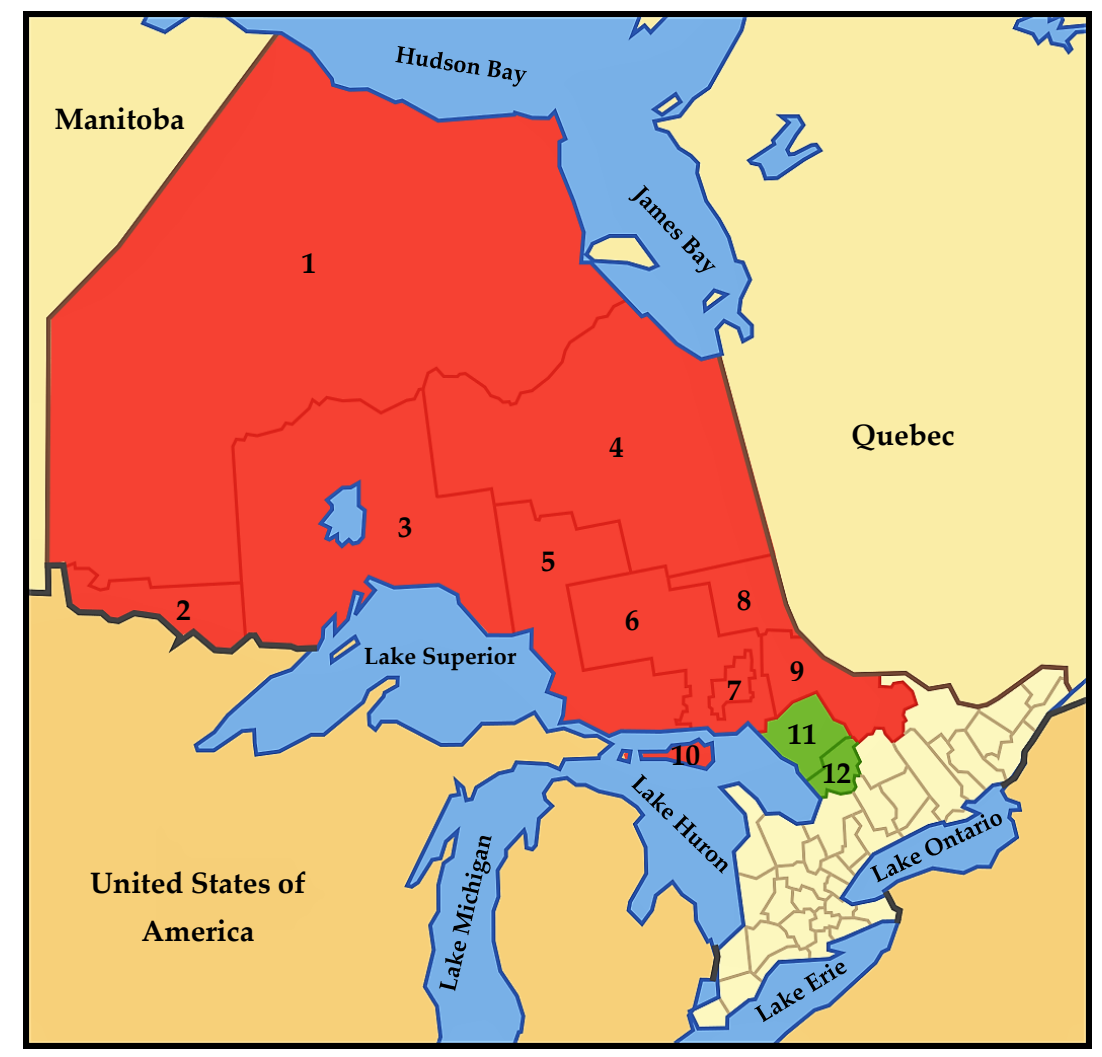

Figure 1. District/regions in Northern Ontario. Legends: 1. Kenora, 2. Rainy River, 3. Thunder Bay, 4. Cochrane, 5. Algoma, 6. Sudbury, 7. Greater Sudbury Division, 8. Temiskaming, 9. Nipissing, 10. Manitoulin, 11. Parry Sound, and 12. Muskoka. The red area represents the core area; green indicates the extended area (i.e., service area of FedNor); cream/white area represents Southern Ontario; and blue represents lake/water areas.

In ecological terms, Ontario has three different zones with 14 ecoregions and 77 ecodistricts (Figure A1, Table A1) [3]. The northernmost ecozone, also called the Hudson Bay Lowlands Ecozone, constitutes three ecoregions and six ecodistricts encompassing about $25 \%$ of Ontario. A second ecozone that is comprised of Ontario's portion of the national Boreal Shield Ecozone is known as Ontario Shield Ecozone; it constitutes nine different ecoregions and 48 ecodistricts occupying more than half of Ontario (66\%). These two ecozones constitute most of Northern and Eastern Ontario. A third ecozone is called as the Mixedwood Plains Ecozone, which is bounded along its southern and western edges by Lakes Huron, Erie, and Ontario and the St. Lawrence River. It occupies $8.6 \%$ of the province in two ecoregions and 23 ecodistricts [3]. Each zone and/or region has its own character and growing conditions (Table A1), and each is known for producing a range of crops, livestock and processed-food products (Table 1$)$. 
Table 1. Agriculture in Northern Ontario [2]

\begin{tabular}{|c|c|c|c|c|c|c|c|c|c|c|c|c|}
\hline \multirow{2}{*}{$\begin{array}{l}\text { District/ } \\
\text { Regions }\end{array}$} & \multirow{2}{*}{$\begin{array}{c}\text { Total } \\
\text { Farmland } \\
\text { (ha) }\end{array}$} & \multirow{2}{*}{$\begin{array}{l}\text { Percent } \\
\text { Change } \\
\text { from } 2011\end{array}$} & \multirow{2}{*}{$\begin{array}{l}\text { Number } \\
\text { of Farms }\end{array}$} & \multirow{2}{*}{$\begin{array}{l}\text { Cropland } \\
\text { (ha) }\end{array}$} & \multicolumn{2}{|c|}{ Pasturelands (ha) } & \multicolumn{3}{|c|}{ Major Crops } & \multirow{2}{*}{ Livestock } & \multirow{2}{*}{ Poultry } & \multirow{2}{*}{$\begin{array}{c}\text { FCR * } \\
\text { (Million \$) }\end{array}$} \\
\hline & & & & & Seeded & Natural & Field Crops/Pasture & Fruit Crops & Vegetable Crops & & & \\
\hline Algoma & 30,083 & -8.3 & 280 & 11,912 & 3252 & 2780 & \multirow{2}{*}{$\begin{array}{l}\text { Oats and barley for grains, hay, } \\
\text { mixed grains, potatoes, corn } \\
\text { for silage }\end{array}$} & \multirow{3}{*}{$\begin{array}{l}\text { Strawberries, } \\
\text { raspberries }\end{array}$} & \multirow{3}{*}{$\begin{array}{l}\text { Sweetcorn, green } \\
\text { beans, tomatoes, } \\
\text { green peas }\end{array}$} & \multirow{2}{*}{$\begin{array}{l}\text { Beef cows, sheep } \\
\text { and lambs, steers, } \\
\text { dairy cows }\end{array}$} & \multirow{4}{*}{$\begin{array}{l}\text { Poultry } \\
\text { and eggs }\end{array}$} & 15.4 \\
\hline Cochrane & 22,078 & -20.7 & 159 & 7991 & 2337 & 3118 & & & & & & 7.8 \\
\hline $\begin{array}{l}\text { Greater } \\
\text { Sudbury } \\
\text { Division }\end{array}$ & 6455 & -20.3 & 124 & 3135 & 185 & 562 & Potatoes, oats for grains, hay & & & Beef cows, steers & & 8.2 \\
\hline Kenora & 10,610 & -8.7 & 72 & 3601 & 1051 & 1535 & $\begin{array}{l}\text { Hay, oats for grains, mixed } \\
\text { grains, potatoes }\end{array}$ & - & $\begin{array}{l}\text { Green beans, } \\
\text { tomatoes }\end{array}$ & $\begin{array}{l}\text { Beef cows, sheep } \\
\text { and lambs, steers }\end{array}$ & & 2.1 \\
\hline Nipissing & 27,786 & -13.3 & 210 & 13,580 & 1470 & 3804 & $\begin{array}{l}\text { Oats and barley for grains, hay, } \\
\text { mixed grains, potatoes, } \\
\text { soybeans, winter wheat }\end{array}$ & - & $\begin{array}{l}\text { Sweetcorn, green } \\
\text { beans, tomatoes }\end{array}$ & $\begin{array}{l}\text { Sheep and lambs, } \\
\text { beef cows, dairy } \\
\text { cows, steers }\end{array}$ & $\begin{array}{l}\text { Poultry } \\
\text { and eggs, } \\
\text { turkey }\end{array}$ & 11.9 \\
\hline $\begin{array}{l}\text { Rainy } \\
\text { River }\end{array}$ & 61,995 & -19.7 & 235 & 21,583 & 7919 & 18,423 & $\begin{array}{l}\text { Oats for grains, hay, mixed } \\
\text { grains, corn for silage, } \\
\text { soybeans }\end{array}$ & - & \multirow{2}{*}{$\begin{array}{l}\text { Sweetcorn, green } \\
\text { beans, tomatoes, } \\
\text { green peas }\end{array}$} & $\begin{array}{l}\text { Beef cows, steers, } \\
\text { dairy cows, sheep } \\
\text { and lambs }\end{array}$ & \multirow[t]{2}{*}{$\begin{array}{l}\text { Poultry } \\
\text { and eggs }\end{array}$} & 34.9 \\
\hline Sudbury & 17,860 & -4.1 & 138 & 7490 & 1062 & 2781 & $\begin{array}{l}\text { Oats and barley for grains, hay, } \\
\text { corn for silage }\end{array}$ & - & & $\begin{array}{l}\text { Beef cows, dairy } \\
\text { cows, sheep and } \\
\text { lambs, steers, pigs }\end{array}$ & & 4.1 \\
\hline Timiskaming & 71,568 & -4.7 & 356 & 47,257 & 4345 & 6297 & $\begin{array}{l}\text { Oats and barley for grains, hay, } \\
\text { mixed grains, soybeans, } \\
\text { potatoes, corn for silage, } \\
\text { winter wheat }\end{array}$ & - & - & $\begin{array}{l}\text { Dairy and beef } \\
\text { cows, sheep and } \\
\text { lambs }\end{array}$ & Turkey & 61.6 \\
\hline $\begin{array}{l}\text { Parry } \\
\text { Sound }\end{array}$ & 26,848 & -13.9 & 252 & 8177 & 2395 & 3623 & $\begin{array}{l}\text { Hay, oats, mixed grains, } \\
\text { potatoes, winter wheat }\end{array}$ & $\begin{array}{l}\text { Apples, } \\
\text { raspberries }\end{array}$ & $\begin{array}{l}\text { Tomatoes, green } \\
\text { beans }\end{array}$ & $\begin{array}{l}\text { Steers, sheep and } \\
\text { lambs }\end{array}$ & $\begin{array}{l}\text { Poultry } \\
\text { and eggs, } \\
\text { turkeys }\end{array}$ & 6.2 \\
\hline Muskoka & 9545 & -7.7 & 162 & 3150 & 842 & 870 & Hay, Oats, mixed grains & - & $\begin{array}{l}\text { Sweet corn, } \\
\text { tomatoes, green } \\
\text { beans }\end{array}$ & Beef cows & $\begin{array}{l}\text { Poultry } \\
\text { and eggs }\end{array}$ & 3.2 \\
\hline Total & 361,967 & -12.4 & 2391 & 149,095 & 29,389 & 78,670 & $\begin{array}{l}\text { Oats and barley for grains, hay, } \\
\text { potatoes, mixed grains, corn } \\
\text { for silage }\end{array}$ & $\begin{array}{l}\text { Raspberries, } \\
\text { strawberries, } \\
\text { apples }\end{array}$ & $\begin{array}{l}\text { Sweetcorn, green } \\
\text { beans, tomatoes }\end{array}$ & $\begin{array}{l}\text { Dairy and beef } \\
\text { cows, sheep and } \\
\text { lambs, steers, pigs }\end{array}$ & $\begin{array}{l}\text { Poultry } \\
\text { and eggs, } \\
\text { turkey }\end{array}$ & 198.9 \\
\hline
\end{tabular}

* Farm Cash Receipts for main commodities in Northern Ontario, 2016. 
Farming in Northern Ontario has both merits and challenges. This region offers a rich and diverse range of agricultural products that can form the basis of healthy and sustainable local food systems and can make Northern Ontario more food secure. Nevertheless, there exist many challenges that make local food production difficult. However, the peer-reviewed knowledge of key challenges and appropriate strategies to protect and promote local agriculture has received little or no attention. This article explores the existing challenges, discusses potential opportunities and offers possible strategies to develop and promote farming in Northern Ontario.

\section{Major Challenges}

Farming in Northern Ontario involves crops ( $42 \%$ of the total farmland in Northern Ontario), seeded and natural pastures ( $8 \%$ and $22 \%$, respectively) and others (e.g., $28 \%$ with Christmas trees, woodland, wetland and land under summer fallow, etc.) [2]. With the presence of very small (i.e., $5 \%$ with $<10$ acres) to very large ( $>20 \%$ with $>500$ acres) sized farms, farmers in this region have been adopting subsistence to semi/commercial agriculture. The challenges associated with agriculture in Northern Ontario to facilitate a shift from traditional agriculture to more profitable commercial farming are listed below.

\subsection{Extreme Climatic Conditions}

Table A1 shows the variation within Northern Ontario in terms of mean temperature, growing season and annual precipitation. Most of Northern Ontario is situated on the Hudson Bay Lowlands and Ontario Shield Ecozones, a vast rocky plateau where the climate is characterised by considerable extremes of temperature (i.e., very dry and warm in summer, and extremely cold or wet or both in winter, with a mean annual temperature of $-5^{\circ} \mathrm{C}$ to $4{ }^{\circ} \mathrm{C}$ ), lower rainfall (with a mean annual precipitation of 450 to $800 \mathrm{~mm}$ ), and a shorter growing season (with a range of 65 to 180 days) compared to its southern counterpart which experiences a mean annual temperature of $4.9^{\circ} \mathrm{C}$ to $9.4{ }^{\circ} \mathrm{C}$, mean annual precipitation of 800 to $1150 \mathrm{~mm}$, and average growing season ranging between 180 and 250 days [3]. In addition, decreasing amount of snow cover in winter followed by reduced rainfall from May through June in recent years has resulted in extraordinarily dry soil for planting crops in most of Ontario, including Northern Ontario, which may be associated with changing climate [4].

\subsection{Lack of Appropriate Crops and/or Varieties and Crop Diversification}

Less than $1 \%$ (i.e., $~ 362,000$ ha) of the total land area in Northern Ontario is under cultivation [2]. Cultivation is limited to a few crops (e.g., oats, barley, mixed grains, hay, potatoes, berries, apples, etc.) and livestock (e.g., dairy and beef cows, sheep and lambs, pigs, etc.) that are adapted to the local soil and climatic conditions. The presence of a limited high quality arable lands (i.e., Class 1 land) and extreme climatic conditions (i.e., dry summer during crop growth period and very cold or wet or both conditions at harvest) has limited the number of crops and/or varieties available in the region to those that are short-season and resilient to drought conditions.

\subsection{Youth Out-Migration and Aging Population/Labour Shortage}

As mentioned before, Northern Ontario contains only about $6 \%$ of the province's population, and with two-thirds of Northern Ontario's population residing in Northeastern Ontario, the Northwestern region is very sparsely populated. Temporary or permanent migration of youth from the North to the South in search of higher-paying jobs and better opportunities, and an increasing number of older than average people has further exacerbated the situation [5]. It is projected that one-fourth of the population of the major cities in Northern Ontario will be over age 65 by the end of the first quarter of the 21st century, thus doubling the current number of people over 65 in the region, which may create chronic and critical labour shortages in the agrifood sector. This is considered as one of the most pressing risks for the agriculture sector in Canada and a major constraint on both agricultural growth and global competitiveness [6]. 


\subsection{Insufficient Infrastructure and Support Services}

Commercialisation and mechanisation of agriculture requires efficient infrastructure to enable production, shipping and distribution of food products, as well as other support services (e.g., tile drainage and land clearing capabilities-without which cash crop production is almost impossible; as well as tools and equipment for farm mechanisation, storage structures, logistics, retail support, grain handling and processing) and market development [7]. With less than $5 \%$ of Ontario's farms situated in this region, the region has small local markets located at some distance from larger markets, a lack of economic diversification, government dependency and a lack of investment potential [5]. Inefficient transportation systems due to insufficient secondary road and rail systems combined with limited access to natural gas has made the post-harvest operation (e.g., drying, heating, processing) difficult and expensive.

\subsection{Meeting the Needs of Aboriginal/First Nations Growers and Consumers}

Ontario is home to 210,000 First Nations peoples (25\% of the First Nations peoples in Canada), 86,000 Métis (19\%), 3400 Inuit (6\%) and over 8000 people of other aboriginal identity [8]. Over one-half of Ontario's aboriginals reside in non-metro census divisions (CDs), predominantly in the north, where more than $10 \%$ of the population is aboriginal (Manitoulin with $41 \%$, Kenora with $36 \%$, Rainy River with $22 \%$, Sudbury with $16 \%$, Cochrane with $13 \%$, Algoma with $12 \%$, Thunder Bay with $12 \%$ and Nipissing with $11 \%$ ) [9].

People from different First Nations ethnicities are located in cities and towns across Northern Ontario. The common First Nations ethnicities include the Anishinaabe, Haudenosaunee and the Cree while there are reserves of the Mohawk, Cayuga, Onondaga, Oneida, Seneca and Tuscarora in its Southern counterpart. The First Nations communities in most of the non-metro CDs are poor and depend on fishing, hunting, gathering of wild as well as underutilised fruits and vegetables, and subsistence farming, for their livelihood. They suffer from high disease and mental health problems as well as suicide rates compared to non-aboriginal people, and hence, require effective strategies to meet their needs [10].

\subsection{Inadequate Policy Support}

Northern Ontario does not fit easily into the image that most Canadians have of Ontario [5]. There exists disparity between the north and south within Ontario in terms of economy, population, market and infrastructure development, and this is reflected when provincial and federal government policies are formulated [11]. As a result, agriculture is one of the neglected and vulnerable sectors in Northern Ontario. Provincial and federal agricultural policies mainly favour production, distribution and marketing of large scale agricultural production systems in Southern Ontario, while the policy support to protect and promote local food systems and food security in Northern Ontario including aboriginals/First Nations peoples, is inadequate [11,12].

\section{Potential Opportunities}

Despite the above challenges, there is tremendous potential to expand the amount of cropland and increase farmers' net return from Northern Ontario agriculture. This region offers a wide range of opportunities to grow a fair to wide range of crops, livestock and forest species alone or in combination. Criteria for selecting crops include those that are adapted to the local context, require low inputs, increase nutrition and/or income and promote climate change resiliency. Specifically, Northern Ontario offers the following opportunities to intensify and diversify its agriculture sector.

\subsection{Fertile Soils for Crop Production}

Northern Ontario, and in particular the Northern Clay Belt Region, is Ontario's newest region of agricultural opportunities [2]. This region offers rich and fertile land formed by the draining 
of a glacial lake thousands of years ago. It stands out from the surrounding boreal forest because of its unusually flat topography and easily-accessible water table [13]. According to the Canada Land Inventory, the Northern Clay Belt region represents 9\%, 50\% and 68\% of Ontario's Class 2, 3 and 4 lands, respectively, which are suitable for cultivation for a fair-to-wide range of crops with moderate-to-special conservation practices (please refer to Table A2 for land classes, descriptions and limitations).

The Northeastern region encompasses more than 16 million acres of potentially fertile lands, of which $\sim 4$ million acres could easily be converted into farmland [13]. This offers the largest untapped reserve of agricultural lands in Canada, which could double the amount of cropland currently being farmed in the entire province. The region providing an abundance of very productive and affordable agricultural land, a changing climate, and a strong tradition of agricultural research and innovation, is increasingly attractive for cultivation.

\subsection{Changing Climate Favours Diversification/Integrated Farming}

A changing climate is dramatically improving growing conditions in the North by expanding cropping options and increasing yields. A number of trends have revolutionised the crops that can be grown in Northern Ontario: increasing temperature, with the average annual temperature projected to increase by $2.5^{\circ} \mathrm{C}$ to $3.7^{\circ} \mathrm{C}$ by the 2050s [14]; already significant increases in corn heat units (CHU), from 1650 in the 1960s to 2175 in 2010 in the Kapuskasing region, for example [15]; increased annual precipitation [14]; and development of new crop varieties and agronomic practices $[16,17]$.

Historically, the main crops in Northern Ontario have been oats ( $28 \%$ of the province's production), barley $(15 \%)$, hay $(12 \%)$, mixed grains $(5 \%)$ and potatoes $(5 \%)$; while other crops are on the rise: canola (production doubled between 2006 and 2016), silage corn ( $2 \%$ of the province's production), soybeans $(1 \%)$, green peas $(1 \%)$ and winter wheat $(0.5 \%)$ [2]. In addition to growing crops, the region is well suited to forage production, e.g., alfalfa, clover, birdsfoot trefoil and temperate forage grasses, and is capable of supporting large herds of grazing livestock: beef and dairy cows (14\% of the province's production), and sheep and lambs (4\%). It is obvious that farmers will undertake new activities (i.e., crops, forages and livestock) primarily if there is a direct and obvious economic benefit from the selected interventions over existing practices.

Diversification is also favoured by an extension of the growing season in the region over the past three decades, tempered by the moderating influence of Hudson Bay and James Bay, which has resulted in a positive impact on crop production. For example, the traditional barley, oat and wheat crops in the Cochrane-Kapuskasing area have been supplemented by canola and other cash crops such as quinoa that look promising [13]. In addition, the northern latitude provides the area with the same extensive summer sunshine enjoyed by Canadian farms to the west (e.g., Manitoba, Saskatchewan). This favours the production of a variety of fruit crops (e.g., northern-hardy varieties), specialty crops (e.g., quinoa, amaranth and hemp), bioenergy crops (e.g., switchgrass, miscanthus and corn) and oilseed crops (e.g., canola, soybeans and camelina), as well as promotes the introduction of new practices (e.g., intensive rotational grazing, pasture improvement, use of cover crops and no-till seeding to improve crop yields while maintaining soil fertility) that are currently only sporadically used in Northeastern Ontario [7].

\subsection{Transportation Services}

Northern and Eastern Ontario have excellent primary road networks and connectivity with ample truck transportation services via the major Canadian highways, e.g., Highways 11, 400, 17, 69, 101, and 144 [13]. Northwestern Ontario, i.e., Kenora, Rainy River and Thunder Bay, is approximately 1400-1850 km from Toronto, while the Northeastern cities of Cochrane, Kapuskasing, New Liskeard, Sudbury, Timmins, Parry Sound, and Huntsville are located within 200-700 km of Toronto. There are an increasing number of support services such as research stations, agriculture associations, grain elevators, and processing facilities in the area. Nevertheless, there remains a significant 
need and demand for farm mechanisation tools and logistics, retail support, grain handling and processing facilities.

\subsection{Inexpensive/Affordable Land for Agriculture}

Land costs in Northeast Ontario are favourable for agriculture (\$4000-6000/acre), typically as little as $10 \%$ of land costs in Southern Ontario [7,13]. As a result, property taxes are also lower, and the overall cost of doing business in the North is potentially quite affordable, which helps make agribusiness more profitable provided that a good income stream can be established.

\section{Needs and Priorities}

The following strategies may be helpful to build a more competitive and sustainable agrifood sector in Northern Ontario. The key lies in setting priorities and building relationships through networking and collaboration among research centres; building capacities of local producers and businesses in the agrifood sector through practical workshops, information-sharing and assisting with market development; and undertaking innovative research that addresses the needs of local producers by conducting on-farm as well as on-station trials and fostering regional research centres (e.g., by the provincial and federal governments as well as by the private sector) that can help improve the sector.

\subsection{Produce and Consume Local Foods}

A tremendous amount of food can be produced by expanding production in Northeast Ontario by utilising its unused fertile soils suitable for cultivation. This will contribute to a sustainable local food source for Northern Ontario residents and beyond. Increasing consumer awareness and/or encouraging Ontarians to buy Ontario-grown foods (buy-local) may help establish market opportunities for local products. This further helps protect and promote local agriculture and markets.

\subsection{Meeting the Needs of Aboriginals/First Nations Growers and Consumers}

The needs of aboriginals/First Nations should be emphasised while formulating policies and programs in Northern Ontario. This includes access to local foods (i.e., fresh fruits/vegetables), employment as well as improved access to traditional foods and high value medicinal plants, and mental health counselling services to youth and other people in need. Opportunities to domesticate certain wild foods or bring them into wider cultivation and export from the region should be further investigated. Targeting agriculture to these communities would meet local needs and there should be ample funding opportunities. Promoting agriculture in First Nations schools would also be useful.

\subsection{Testing/Adoption of Appropriate Crops and Cropping Systems Suitable for the Region}

Introduction and evaluation of drought-tolerant and/or high-yielding cash/specialty crops/ forages (e.g., short season corn, canola, winter wheat, soybean, sunflower, quinoa, amaranth, switch grass, miscanthus, alfalfa, clover, etc.) for regional adaptability and profitability may help effectively utilise the shorter growing season in the North. There exists potential of planting short-season corn and soybeans in a two-year rotation or alternatively, corn, soybean and winter wheat in a three-year rotation in the Northeastern region as cash and/or bioenergy crops as seen in Eastern and Southern Ontario [16].

However, attention should be given for the development of cropping systems that are energy efficient, soil/water conserving and non-polluting. This can be achieved by testing soil to optimise nutrient requirements (including micronutrients) of major field crops using the $4 \mathrm{R}$ principles (i.e., right source, right rate, right time and right place); designing low cost and sustainable agro-ecosystems (e.g., cover crops/intercropping, crop rotation, conservation tillage, adoption of $4 \mathrm{R}$ nutrient management strategies, etc.) that reduce the use of synthetic fertilisers in crop production; and by providing tools and practices (i.e., genetic selection, optimal crop and soil management practices, 
and field testing of precision agriculture techniques) that sustain ecosystem services, input efficiency and environmental quality while adapting to climatic extremes [17-22]. Selection of crops and/or varieties with different root architectures (i.e., longer and finer roots, including greater number of tips and branching angle, and a lower shoot: root ratio) may also help tolerate drought conditions [23,24]. Intensive rotational grazing and forage/pasture improvement practices may be useful to feed an increasing number of livestock in the region.

It is important to note that on-station trials cannot substitute for on-farm trials. Working closely with innovative growers/early adopters by establishing on-farm trials and/or piggybacking onto existing on-station, field-scale research trials at different locations in Northern Ontario to evaluate a limited set of environmental, agronomic and economic indicators under 'real-world' conditions is equally important. This also helps disseminate any effective, novel results for wider adoption by growers.

\subsection{Collaboration and Capacity Development}

The key lies in knowledge transfer and grower capacity building through exchange of information between researchers/agronomists, growers, grower organisations, government specialists, and regional community organisations and commodity groups that help develop new opportunities in the region. Networks and actors include, e.g., the Northeast Community Network $(\mathrm{NeCN})$, the Ontario Federation of Agriculture (OFA), the Agricultural Adaptation Council (AAC), the Beef Farmers of Ontario (BFO), the Christian Farmers Federation of Ontario (CFFO), the Ontario Soil and Crop Improvement Association (OSCIA), the Ontario Woodlot Association (OWA), the Ontario Maple Syrup Producers Association (OMSPA), the Algoma Community Pasture Association (ACPA), representatives of the private sector (e.g., the Algoma Mutual Insurance Company (AMIC), the Cooks Station Corporation, etc.), agencies of the provincial and federal governments [e.g., the Ontario Ministry of Agriculture, Food and Rural Affairs (OMAFRA), the Ontario Ministry of Infrastructure and Ministry of Northern Development, Mines and Forestry, FedNor, the Northern Ontario Heritage Fund Corporation (NOHFC), the Ontario Trillium Foundation (OTF), and Agriculture and Agri-Food Canada (AAFC)]; and regional districts/cities in Northern Ontario (e.g., Thunder Bay, Rainy River, Kenora, Timiskaming, Cochrane, Sudbury, Nipissing, Parry Sound, Muskoka, Algoma and Manitoulin), as well as research institution/stations (e.g., NORDIK Institute, the Thunder Bay Agricultural Research Station (TBARS)), and innovation centres (e.g., the Sault Ste. Marie Innovation Centre-(SSMIC), the Northern Ontario Farm Innovation Alliance (NOFIA)). These community-based initiatives, supported by an informed population and strong tourism industry, can be supported by establishing dedicated funds for local agriculture research, innovation and infrastructure development. There is a need for an independent Northern Agricultural Research Institute taking all northern research stations into its fold.

\subsection{Effective Use of Different Extension Avenues}

Effective dissemination of appropriate science-based solutions is required to achieve the ultimate goal of helping growers and other stakeholders in the region. This can be achieved by presenting innovative ideas and research findings at farm conferences (e.g., Farm Smart); effective use of digital media (e.g., website postings, issuing online reports for growers and stakeholders, webinars, use of social media, Twitter, TV, radio and popular press); small group meetings, field visits and demonstrations (e.g., commodity group meeting, open house, etc.); development of peer-reviewed publications, extension materials and magazine reports (e.g., Canadian Journal of Plant Science, Agronomy Journal, Ontario Grain Grower, Top Crop Manager, The Western Producer, commodity magazines, etc.) and presenting at semi or annual meetings (e.g., Canadian Society of Agronomy, Canadian Society for Horticultural Science, etc.) to engage growers and other stakeholders as well as to exchange ideas. Also important is the exchange of information through the Certified Crop Advisors (CCAs) and other extension personnel working in the region. 


\subsection{Infrastructure and Market Development}

Improved transportation/road networks for shipping and distribution of goods and services to distant markets as well as to population centres is required for sustained growth of the agriculture sector in Northern Ontario. Establishment of a four-lane road transportation corridor, maintenance of current secondary rail and road systems to travel through regions where soil is good, and an adequate Trans-Canada highway linking Northern Ontario to Eastern and Western Ontario is important [5]. Other supporting infrastructure (e.g., tile drainage and land clearing capacities, tools and equipment for farm mechanisation, storage structures, grain handling and processing structures, as noted above) and market services (e.g., support for the establishment of the distribution systems, expansion of farmers' markets/food co-ops, building on brands by improving regional branding initiatives and producer-led branding initiatives, and by assessing the viability of wholesalers for local food-co-packing, shipping and distribution, etc.) are required to foster agriculture in the Northeast region [7]. Furthermore, there exist opportunities for farms that comply with food-for-safety programs (i.e., the CanadaGAP ${ }^{\circledR}$, Ottawa, ON, Canada) to sell product to larger retailers, hospitals, schools and government institutions.

\subsection{Policy Support}

Policies to attract farmers and immigrants who are new to the region as well as new to the industry by assisting them to establish new farms, as well as strategies to assist existing farmers with their succession planning, may further assist continuance of the farming profession in the Northeast. Strategies to retain youth by increasing opportunities (i.e., study, work) in local colleges, universities and through vocational training in the agrifood sector, as well as by creating careers in eldercare, may help improve labour shortages [5]. Also, a business risk management program and agri-insurance to address production losses associated with events like dry weather is an effective strategy to support growers who experienced damage to their insured crops or forages, to help sustain their agricultural operations [4].

\section{Conclusions}

With less than $1 \%$ of its total land area currently under cultivation, Northern Ontario is home of 2391 farms generating $\$ 199$ million in revenue. This region supports at present a significant number of communities within Ontario that depend on a currently unsustainable food system and have a lack of food security. This paper identifies some major challenges faced by Northern Ontario agriculture as well as opportunities that this region could capitalise on. Some of the major challenges include: the presence of limited high quality arable land and extreme climate, labour shortages resulting from an older than average population, low wages in agricultural work, lack of interest among youth, and inadequate policy support from the local, provincial and federal governments to protect and promote local agriculture.

Given that this region has a tremendous amount of land that is classified as type 2, 3 or 4 which can be brought under cultivation for a fair-to-wide range of crops with moderate-to-special conservation practices, there could potentially be a doubling of the amount of cropland currently being farmed in the entire province. This requires development and dissemination of science-based solutions with a focus on growth, competitiveness, sustainability and adaptability of the agrifood sector by: (1) evaluating cultivars of major cash/specialty crops/forages (e.g., short season corn, canola, winter wheat, soybean, sunflower, quinoa, amaranth, switch grass, miscanthus, alfalfa, clover, etc.) for regional adaptability and profitability; (2) optimising nutrient requirements (including micronutrients) of major field crops, using the $4 \mathrm{R}$ principles (i.e., right source, right rate, right time and right place); (3) designing low-cost and sustainable agro-ecosystems (e.g., cover crops/intercropping, crop rotation, conservation tillage, adoption of $4 \mathrm{R}$ nutrient management strategies, etc.) that reduce the use of synthetic fertilisers in crop production; (4) providing tools and practices (i.e., genetic selection, optimal crop and soil management practices, and field testing of precision ag techniques) 
that sustain ecosystem services, input efficiency and environmental quality while adapting to climatic extremes; and (5) meeting the needs of First Nations and disadvantaged peoples through access to local foods (i.e., fresh fruits/vegetables), employment as well as improved access to traditional foods and high value medicinal plants. Strategies discussed in this paper could be supported by formalised government policies and community organisations dedicated to the well-being of Northern Ontario agriculture, which will help to maintain ecosystems including the diversity of crops that can be cultivated to maintain food security in the region including the First Nations.

Acknowledgments: My thanks go to Norman Uphoff, Professor of Government and International Agriculture at Cornell University and Manish Raizada at the University of Guelph for editing this manuscript. Sincere thanks to farmers and community organisations as well as research institutions and innovation centres dedicated to the well-being of Northern Ontario, which is a source of inspiration for the author. Members of the Raizada Lab (University of Guelph) and the researchers associated with a long-term cover crop project funded by the Ontario Ministry of Agriculture, Food and Rural Affairs (OMAFRA) and Grain Farmers of Ontario (GFO) also deserve special thanks and appreciation.

Conflicts of Interest: The author declares no conflict of interest.

\section{Appendix A.}

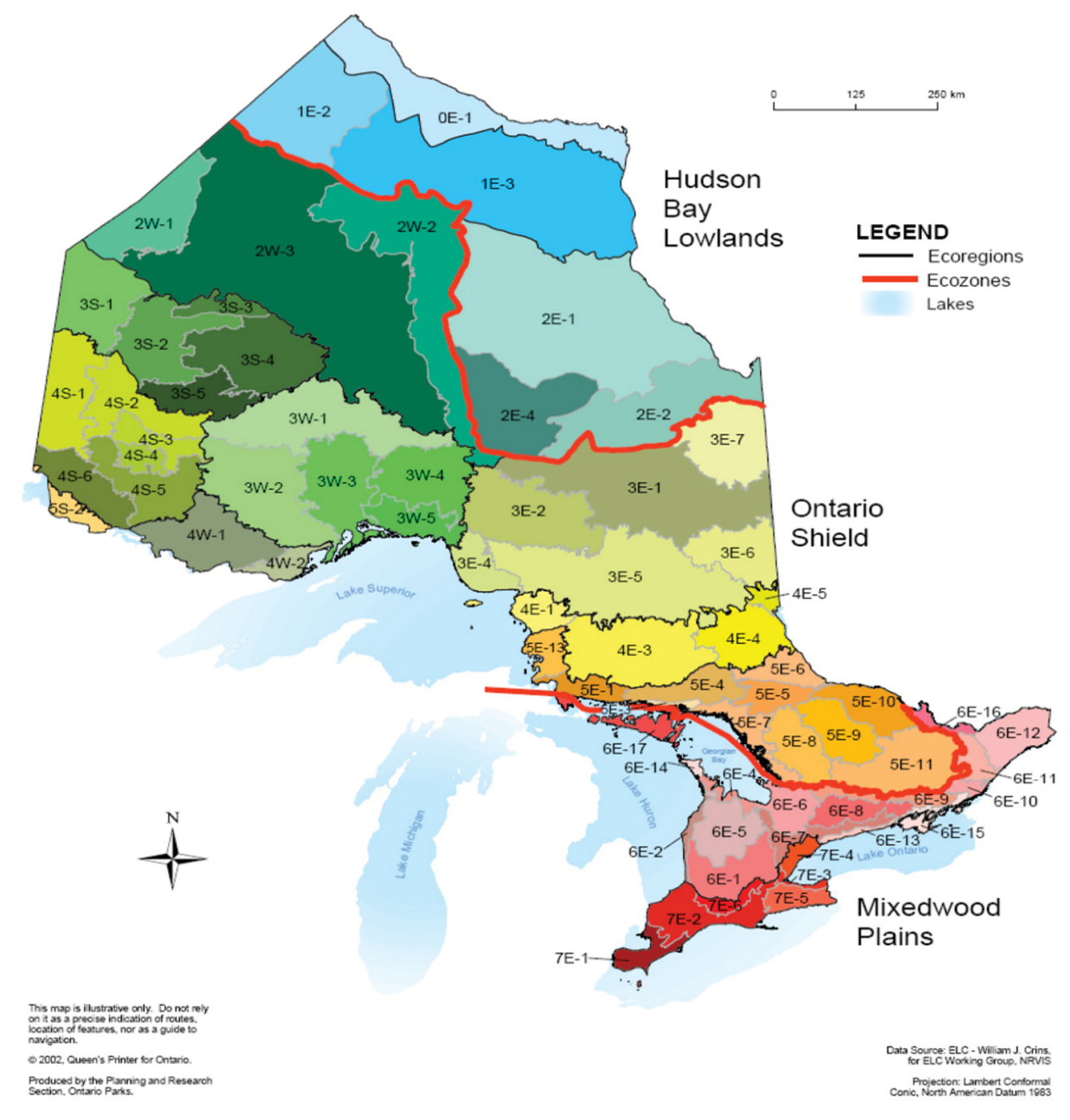

Figure A1. The ecozones, ecoregions and ecodistricts of Ontario [3]. 
Table A1. Characteristics of ecozones and associated ecoregions in Ontario [3].

\begin{tabular}{|c|c|c|c|c|c|c|}
\hline Ecozone * & Ecoregion ** & $\begin{array}{l}\text { Number of } \\
\text { Ecodistricts }\end{array}$ & Primary Bedrock ${ }^{1}$ & $\begin{array}{c}\text { Mean Annual } \\
\text { Temperature }{ }^{2}\left({ }^{\circ} \mathrm{C}\right)\end{array}$ & $\begin{array}{c}\text { Mean Annual } \\
\text { Precipitation }{ }^{2}(\mathrm{~mm})\end{array}$ & $\begin{array}{l}\text { Average Growing Season } \\
\text { (Length-Days) }^{2}\end{array}$ \\
\hline \multirow{3}{*}{$\begin{array}{l}\text { Hudson Bay } \\
\text { Lowlands }\end{array}$} & 0E-Hudson Bay Coast & 1 & \multirow{3}{*}{$\begin{array}{l}\text { Phanerozoic } \\
\text { Calcareous }\end{array}$} & -5.1 to -2.2 & $490-614$ & 65 \\
\hline & 1E-Northern Taiga & 2 & & -5.1 to -2.2 & $490-614$ & $138-157$ \\
\hline & 2E-James Bay & 3 & & -2.6 to 0.5 & $528-833$ & $154-173$ \\
\hline \multirow{9}{*}{ Ontario Shield } & 2W-Big Trout Lake & 3 & \multirow{7}{*}{$\begin{array}{l}\text { Archean Acidic/ } \\
\text { Metamorphic }\end{array}$} & -4.1 to -0.1 & $550-786$ & $147-170$ \\
\hline & 3E-Lake Abitibi & 7 & & -0.5 to 2.5 & $652-1029$ & 167-185 \\
\hline & 3S-Lake St. Joseph & 5 & & -1.7 to 1.0 & $613-787$ & $162-179$ \\
\hline & 3W-Lake Nipigon & 5 & & -1.7 to 2.1 & $654-879$ & $161-182$ \\
\hline & 4E-Lake Temagami & 5 & & 0.8 to 4.3 & $725-1148$ & $171-200$ \\
\hline & 4S-Lake Wabigoon & 6 & & 0.1 to 2.6 & $565-724$ & $174-188$ \\
\hline & 4W-Pigeon River & 2 & & 0.2 to 2.7 & $674-838$ & $168-188$ \\
\hline & 5E-Georgian Bay & 13 & \multirow{2}{*}{$\begin{array}{l}\text { Proterozoic Acidic/ } \\
\text { Metamorphic }\end{array}$} & 2.8 to 6.2 & $771-1134$ & $183-219$ \\
\hline & 5S-Agassiz Clay Plain & 2 & & 1.4 to 2.8 & $559-660$ & $182-190$ \\
\hline \multirow{2}{*}{ Mixedwood Plains } & 6E-Lake Simcoe-Rideau & 17 & \multirow{2}{*}{$\begin{array}{l}\text { Phanerozoic } \\
\text { Calcareous }\end{array}$} & 4.9 to 7.8 & 759-1087 & 205-230 \\
\hline & 7E-Lake Erie-Lake Ontario & 6 & & 6.3 to 9.4 & 776-1018 & $217-243$ \\
\hline
\end{tabular}

${ }^{1}[25] ;{ }^{2} 0 \mathrm{E}-[26]$; and rest [27]; ${ }^{*}$ An ecozone is a very large area of land and water characterised by a distinctive bedrock domain that differs in origin and chemistry from the bedrock domain immediately adjacent to it; ${ }^{* *}$ An ecoregion is a unique area of land and water nested within an ecozone that is defined by a characteristic range and pattern in climatic variables, including temperature, precipitation and humidity. 
Table A2. Land classes in Canada and their characteristics [28]

\begin{tabular}{|c|c|c|}
\hline Classification & Description & Limitation \\
\hline Class 1 & $\begin{array}{l}\text { The soils are deep, are well to imperfectly drained, hold moisture well, and well supplied with plant } \\
\text { nutrients. They can be managed and cropped without difficulty. Under good management, they are } \\
\text { moderately-high to high in productivity for a wide range of field crops. }\end{array}$ & $\begin{array}{l}\text { Soils in this class have no significant limitations } \\
\text { in use for crops. }\end{array}$ \\
\hline Class 2 & $\begin{array}{l}\text { The soils are deep and hold moisture well. The limitations are moderate and the soils can be managed } \\
\text { and cropped with little difficulty. Under good management, they are moderately-high to high in } \\
\text { productivity for a fairly wide range of field crops. }\end{array}$ & $\begin{array}{l}\text { Soils in this class have moderate limitations that } \\
\text { restrict the range of crops or require moderate } \\
\text { conservation practices. }\end{array}$ \\
\hline Class 3 & $\begin{array}{c}\text { The limitations are more severe than for class } 2 \text { soils. They affect one or more of the following } \\
\text { practices: timing and ease of tillage, planting and harvesting, choice of crops and methods of } \\
\text { conservation. Under good management, they are fair to moderately high in productivity for a fair } \\
\text { range of field crops. }\end{array}$ & $\begin{array}{l}\text { Soils in this class have moderately severe } \\
\text { limitations that restrict the range of crops or } \\
\text { require special conservation practices. }\end{array}$ \\
\hline Class 4 & $\begin{array}{l}\text { The limitations seriously affect one or more of the following practices: timing and ease of tillage, } \\
\text { planting and harvesting, choice of crops and methods of conservation. The soils are low to fair in } \\
\text { productivity for a fair range of crops but may have high productivity for a specially adapted crop. }\end{array}$ & $\begin{array}{l}\text { Soils in this class have severe limitations that } \\
\text { restrict the range of crops or require special } \\
\text { conservation practices or both. }\end{array}$ \\
\hline Class 5 & $\begin{array}{l}\text { The limitations are so severe that the soils are not capable of sustained production of annual field } \\
\text { crops. The soils are capable of producing native or tame species of perennial forage plants, and may } \\
\text { be improved by use of farm machinery. The improvement practices may include clearing bush, } \\
\text { cultivation, seeding, fertilizing, or water control. }\end{array}$ & $\begin{array}{l}\text { Soils in this class have very severe limitations } \\
\text { that restrict their capability to producing } \\
\text { perennial forage crops, and improvement } \\
\text { practices are feasible. }\end{array}$ \\
\hline Class 6 & $\begin{array}{l}\text { These soils provide some sustained grazing for farm animals, but the limitations are so severe that } \\
\text { improvement by use of farm machinery is impractical. The terrain may be unsuitable for use of farm } \\
\text { machinery, or the soils may not respond to improvement or the grazing season may be very short. }\end{array}$ & $\begin{array}{l}\text { Soils in this class are capable only of producing } \\
\text { perennial forage crops, and improvement } \\
\text { practices are not feasible. }\end{array}$ \\
\hline Class 7 & This class also includes rock land, non-soil areas and bodies of water too small to show on maps. & $\begin{array}{l}\text { Soils in this class have no capability for arable } \\
\text { culture or permanent pasture. }\end{array}$ \\
\hline Class 0 & his class includes marshes, peats, bogs and swamps. & - \\
\hline
\end{tabular}




\section{References}

1. Statistics Canada. 2016 Census of Agriculture. Available online: http://www.statcan.gc.ca/eng/ca2016 (accessed on 12 July 2017).

2. Ontario Ministry of Agriculture, Food and Rural Affairs-OMAFRA. Available online: http://www.omafra. gov.on.ca/english/stats/county/ (accessed on 18 July 2017).

3. Crins, J.W.; Gray, A.P.; Uhlig, C.P.W.; Wester, C.M. The Ecosystems of Ontario, Part 1: Ecozones and Ecoregions; Technical Report SIB TER IMA TR-01; Ontario Ministry of Natural Resources, Queen's Printer for Ontario: Toronto, ON, Canada, 2009.

4. Legislative Assembly of Ontario-LAO. Committee Documents: Standing Committee on Estimates-2016-Nov-01-Ministry of Agriculture, Food and Rural Affairs. Available online: http:/ / www.ontla.on.ca/web/committeeproceedings / committee_transcripts_details.do?locale=en\& BillID=\&ParlCommID=8996\&Date=2016-11-01\&Business=Ministry\%20of\%20Agriculture, \%20Food\% 20and\%20Rural\%20Affairs\&DocumentID=31192 (accessed on 14 March 2017).

5. Woodrow, M. Challenges to sustainability in Northern Ontario; A Report for the Environmental Commissioner of Ontario; Institute of the Environment, University of Ottawa: Ottawa, ON, Canada, 2002; p. 18.

6. Canadian Federation of Agriculture-CFA. Addressing Agriculture's Labour Shortage. Available online: http: / / www.cfa-fca.ca/wp-content/uploads/2017/01/Labour-Brief-Oct2016.pdf (accessed on 16 March 2017).

7. Caldwell, E. Building Capacity for Northern Ontario Agriculture. Available online: http: / / www.farmnorth.com/websites/farmnorth.com/images/research/Building\%20Capacity\%20for\% 20Northern\%20Ontario.pdf (accessed on 18 May 2017).

8. Statistics Canada. Aboriginal Peoples: Fact Sheet for Ontario. Available online: http://www.statcan.gc.ca/ pub/89-656-x/89-656-x2016007-eng.htm (accessed on 28 July 2017).

9. Rural Ontario Institute-ROI. Aboriginal identity population. Focus Rural Ont. 2013, 1, 1-2.

10. Hay, D.; Varga-Toth, J.; Hines, E. Frontline Health Care in Canada: Innovations in Delivering Services to Vulnerable Populations; Research Report F/63; Family Network; Canadian Policy Research Networks Inc.: Ottawa, ON, Canada, 2006.

11. Local Food Solution-LFS. Agriculture in Muskoka-Tools for a Sustainable Future. Available online: https://muskoka.civicweb.net/document/17975/LFS_Final\%20reduced.pdf?handle= 3E879C37D14E4B8FB220462796497BF8 (accessed on 12 June 2017).

12. Dawson, B. The roots of agriculture: A historiographical review of First Nations agriculture and government Indian policy. Prairie Forum 2003, 28, 99-116.

13. Northeast Community Network-NeCN. Growing Opportunities in Northeastern Ontario. Available online: http:/ / www.opportunitiesnortheastontario.ca/ (accessed on 14 June 2017).

14. Canadian Climate Data and Scenarios-CCDS. 2050s ensemble scenarios (1961-1990 baseline). Canadian Climate Change Scenarios Network. Adaptation and Impacts Research Section, Environment Canada. Available online: http:/ / ccds-dscc.ec.gc.ca/?page=ensemblescenarios-2050s (accessed on 14 May 2017).

15. Bootsma, A. Decadal Trends in Crop Heat Units for Ontario and Quebec from 1951 to 2010. Available online: https:/ / www.agrireseau.net/Agroclimatologie/documents/Ontario $\% 20$ Quebec $\%$ 20CHU\%20trends\%202012.pdf (accessed on 18 May 2017).

16. Kludze, H.; Deen, B.; Weersink, A.; van Acker, R.; Janovicek, K.; Laporte, A.D. Assessment of the Availability of Agricultural Biomass for Heat and Energy Production in Ontario. A Report for the Ontario Ministry of Agriculture, Food and Rural Affairs (OMAFRA). Available online: https://www.uoguelph.ca/plant/research/agronomy/publications/pdf/Ontario_Biomass_Availability_ Project_Final_Report_2011.01.27.pdf (accessed on 14 June 2017).

17. Chapagain, T.; Good, A. Yield and production gaps in rainfed wheat, barley and canola in Alberta. Front. Plant Sci. 2015, 6, 990. [CrossRef] [PubMed]

18. Chapagain, T.; Raizada, M.N. Agronomic challenges and opportunities for smallholder terrace agriculture in developing countries. Front. Plant Sci. 2017, 8, 331. [CrossRef] [PubMed]

19. Chapagain, T.; Raizada, M.N. Impacts of natural disasters on smallholder farmers: Gaps and recommendations. Agric. Food Secur. 2017, 6, 39. [CrossRef]

20. Chapagain, T.; Riseman, A. Barley-pea intercropping: Effects on land productivity, carbon and nitrogen transformations. Field Crops Res. 2014, 166, 18-25. [CrossRef] 
21. Chapagain, T.; Riseman, A. Nitrogen and carbon transformations, water use efficiency and ecosystem productivity in monocultures and wheat-bean intercropping systems. Nutr. Cycl. Agroecosyst. 2015, 101, 107-121. [CrossRef]

22. Chapagain, T.; Riseman, A. Intercropping wheat and beans: effects on agronomic performance and land productivity. Crop Sci. 2014, 54, 2285-2293. [CrossRef]

23. Chapagain, T.; Riseman, A. Evaluation of heirloom and commercial cultivars of small grains under low input organic systems. Am. J. Plant Sci. 2012, 3, 655. [CrossRef]

24. Chapagain, T.; Super, L.; Riseman, A. Root architecture variation in wheat and barley cultivars. Am. J. Exp. Agric. 2014, 4, 849-856. [CrossRef]

25. Thurston, P.C. Geology of Ontario: Introduction. In Geology of Ontario. Special Volume 4, Part 1. Ontario Geological Survey; Thurston, P.C., Williams, H.R., Eds.; Queen's Printer for Ontario: Toronto, ON, Canada, 1991; pp. 3-25.

26. McAndrews, J.H.; Riley, J.L.; Davis, A.M. Vegetation history of the Hudson Bay Lowland: A postglacial pollen diagram from the Sutton Ridge. Nat. Canada 1982, 109, 597-608.

27. Mackey, B.G.; McKenney, D.W.; Yang, Y.Q.; McMahon, J.P.; Hutchinson, M.F. Erratum: Site regions revisited: A climatic analysis of hills' site regions for the province of Ontario using a parametric method. Can. J. Res. 1996, 26, 1112. [CrossRef]

28. Agriculture and Agri-Food Canada-AAFC. Canada Land Inventory-Land Capability Class Descriptions for Agriculture. Available online: http://sis.agr.gc.ca/cansis/nsdb/cli/classdesc.html (accessed on 14 June 2017).

(C) 2017 by the author. Licensee MDPI, Basel, Switzerland. This article is an open access article distributed under the terms and conditions of the Creative Commons Attribution (CC BY) license (http://creativecommons.org/licenses/by/4.0/). 